Research Article

\title{
Integrated STEM-based module: Relationship between students' creative thinking and science achievement
}

Ahmad Adnan Mohd Shukri a,1,*, Che Nidzam Che Ahmad a,2, Norhayati Daud a,3

a Department of Biology, Faculty of Science and Mathematics, Sultan Idris Education University, Tanjong Malim, Perak 35900,

Malaysia

1 adnan91shukri@gmail.com*; ${ }^{2}$ nidzam@fsmt.upsi.edu.my; ${ }^{3}$ norhayati.daud@fsmt.upsi.edu.my

* Corresponding author

\begin{tabular}{|c|c|}
\hline ARTICLE INFO & ABSTRACT \\
\hline \multirow[t]{2}{*}{$\begin{array}{l}\text { Article history } \\
\text { Received May 18, } 2020 \\
\text { Revised June 9, } 2020 \\
\text { Accepted June 15, } 2020 \\
\text { Published July 21, } 2020 \\
\text { Keywords } \\
\text { Integrated STEM } \\
\text { Creative thinking } \\
\text { Science achievement }\end{array}$} & $\begin{array}{l}\text { STEM-based learning innovations have been massively developed especially related to } \\
21 \text { st Century skills. This study was done to explore a relationship between creative } \\
\text { thinking and science achievement through the implementation of integrated STEM- } \\
\text { based module on Reproduction topic. A quasi-experimental study involved pretest- } \\
\text { posttest non-equivalent group design with sample of } 60 \text { eighth graders from a boarding } \\
\text { school in Baling, Kedah, Malaysia. The samples was divided into two groups - } 30 \\
\text { students of treatment group and } 30 \text { students of control group. The data were collected } \\
\text { from pre-post-Reproduction Test Questions (RTQ) scores and pre-post-Creative } \\
\text { Thinking Test Questions (CTTQ) scores. Pearson Correlation and one-way ANOVA at a } \\
\text { significance level } p<.05 \text { were performed in analysing data. Findings reveal no } \\
\text { statistically significant relationship between creative thinking and science achievement } \\
\text { for both treatment group ( } r=.220, p=.243 \text { ) and control group ( } r=.308, p=.098 \text { ). } \\
\text { Besides, there is a statistically significant and moderate and positive relationship } \\
\text { between creative thinking indicator of fluency and science achievement ( } r=.463, p= \\
.010) \text { of the treatment group. In conclusion, general finding is an evidence that between } \\
\text { creative thinking and science achievement shows a consistency in whatever teaching } \\
\text { strategy implemented. In which, educators need to realize that academic achievement } \\
\text { does not necessarily be a necessity in shaping one's creativity. Therefore, further study } \\
\text { is needed to investigate the relationship between these variables in the execution of } \\
\text { STEM teaching and learning so that the findings can be generalized to a larger } \\
\text { population. }\end{array}$ \\
\hline & $\begin{array}{r}\text { Copyright } \odot \text { 2020, Shukri, et al } \\
\text { This is an open access article under the CC-BY-SA license }\end{array}$ \\
\hline $\begin{array}{r}\text { creative } \\
\text { org } / 10.2\end{array}$ & $\begin{array}{l}\text { N. C., \& Daud, N. (2020). Integrated STEM-based module: Relationship between students } \\
\text { nce achievement. JPBI (Jurnal Pendidikan Biologi Indonesia), 6(2), 173-180. doi: https://do } \\
236\end{array}$ \\
\hline
\end{tabular}

\section{INTRODUCTION}

STEM education in Malaysia needs to be strengthened as one of the main issues is the existing STEM curriculum operated un-integrated (Bunyamin, 2015; Rauf et al., 2017). In this regard, Ministry of Education (MoE) of Malaysia has taken steps to revise the curriculum and inform the implementation of the secondary school standard curriculum (SSSC) replacing secondary school integrated curriculum in phases beginning in 2017 (Bahrum et al., 2017; Bunyamin \& Finley, 2016). A standard document for curriculum and assessment (SDCA) for all subjects has been enacted and used by teachers to carry out teaching and learning and 
assessment (MoE, 2013; Sulaiman et al., 2015). The SSSC provides learners with a comprehensive set of $21^{\text {st }}$ Century skills and competencies (Scott, 2015).

In terms of pedagogy, the curriculum transformation emphasizes in-depth learning through various approaches involving higher-order thinking skills (McFarlane, 2013) as well as focusing on inquiry-based learning (Prayogi \& Yuanita, 2018), problem-solving (Binkley et al., 2012), contextual learning (Asrizal et al., 2017), collaborative learning (McKechan \& Ellis, 2014), project-based learning (Mustafa et al., 2016; Mustaffa \& Ismail, 2015), and STEM approach (CDD, 2016). In addition to pedagogy, providing teaching and learning resources is essential for teachers to find and use materials from various sources as references (CDD, 2014) and one of them is the use of teaching and learning modules besides using textbooks and digital materials supplied by MoE (MoE, 2013).

STEM-related studies in Malaysia and even in other countries are still lacking. The majority of studies aim to strengthen curriculum development and view the learning outcomes achieved by students who are still in their embryonic stages (English, 2016). While the number of students participating in STEM and their motivation has declined in most western countries (Asghar et al., 2012; Sturyf et al., 2019), some studies have shown that teenager's interest in STEM in developing countries like India and Malaysia are increasing (Thomas \& Watters, 2015). However, more efforts need to be made to strengthen STEM.

Malaysian teachers are still less exposed to STEM, as the approach is relatively new to the country's educators (Bahrum et al., 2017; Rauf et al., 2017). They lack STEM content knowledge and less attention to effective teaching strategies in implementing STEM (Mustafa et al., 2016; Osman \& Saat, 2014). Besides, there are still many teachers who do not consider thinking ability as the focus of teaching. According to (Kadir et al., 2017), science teachers are mainly less focused on executing activities that apply thinking skills. Thus, integrated STEM needs to be implemented as this approach that applies the problem-solving process can foster creative thinking and critical thinking, which are essential skills in ensuring student success. Hence, to strengthen STEM education in Malaysia, professional training needs to be improved and monitored to create competent teachers in terms of knowledge, skills, and attitudes in STEM integration (Bahrum et al., 2017). Besides, Science and Mathematics subjects should also be interesting (Fidan \& Ay, 2016; Thomas \& Watters, 2015), easy to understand (Serrat et al., 2014), emphasizing more hands-on and exploration activities (Hock, 2016; Piergiovanni, 2014).

Little research has been carried out involving STEM integration subjects like Science, Biology, Chemistry, Physics, and Mathematics. Past research on STEM are more prone to focus on higher education (Jayarajah et al., 2014) and less emphasis at school level (Bunyamin, 2015; Jayarajah et al., 2014). The execution of STEM at the school level, especially in secondary school, is still vague to be conducted by the teachers, whereas it is a strategy for increasing students' readiness for post-secondary STEM programs. Therefore, researchers introduced the engineering design process as a teaching strategy in integrating STEM for Science teaching and learning among secondary students through a developed teaching module, named Celik STEM Module.

The developed module consists of four content standard-based learning activities on the topic of Reproduction: sexual and asexual reproduction, the human reproductive system, and factors that influence fetal development, as stated in the SDCA. This module is used in learning these topics so that it is expected to provide an overview of the relationship between scientific achievement and creative thinking. The purpose of this study was to answer (1) whether there are significant differences between indicators of originality, fluency, flexibility, elaboration based on the level of scientific achievement, and (2) a significant relationship between creative thinking and scientific achievement between treatment and control groups.

More specifically, these research questions test the following hypotheses: $\left(H_{01}\right)$ There is no statistically significant difference between creative thinking indicator of originality, fluency, flexibility and elaboration based on science achievement level of the treatment group; $\left(\mathrm{H}_{02}\right)$ There is no statistically significant difference between creative thinking indicator of originality, fluency, flexibility and elaboration based on science achievement level of the control group; $\left(\mathrm{H}_{03}\right)$ There is no statistically significant relationship between creative thinking and science achievement of the treatment group; $\left(\mathrm{H}_{04}\right)$ There is no statistically significant relationship between creative thinking and science achievement of the control group; $\left(\mathrm{H}_{05}\right)$ There is no statistically significant relationship between creative thinking indicator of originality, fluency, flexibility and elaboration and science achievement of the treatment group; $\left(\mathrm{H}_{06}\right)$ There is no statistically significant relationship between creative thinking indicator of originality, fluency, flexibility and elaboration and science achievement of the control group.

\section{METHOD}

In this study, researchers did not randomly assign participants to groups. In other words, researchers did not control the assignment to groups. Consequently, the groups may be different before the study; thus, a 
pretest is essential to be administered so that the sample groups are initially equivalent in terms of the aspects studied (e.g., creative thinking and science achievement). About what has been mentioned, this study involved a quasi-experimental with the type of pretest-posttest non-equivalent group design. Concerning this research design, a treatment group was given a pretest, received a treatment in which the sample engaged in teaching and learning using Celik STEM Module, and was then given a post-test. At the same time, there was a nonequivalent control group that was given a pretest, had been educated using the traditional teaching method instead of using Celik STEM Module, and then was given a post-test. Both groups had been taught by the same teacher with different teaching methods. In terms of the difference in pretest-posttest execution time, the pretest was conducted in the first week for both groups before the treatment where reproduction test questions (RTQ) was administered on the first day while creative thinking test questions (CTTQ) was carried out on the next day. After implementing the treatment for eight weeks, the post-test was given to both groups in a tenth week. Pretest and post-tests were administered with the same instruments that consisted of the same questions for RTQ and CTTQ.

Researchers conducted the study at one of the boarding schools in Baling, Kedah, Malaysia. A random cluster sampling was used where whole groups (six classes of eighth-graders) were randomly selected instead of individuals (Idris, 2013). In this way, researchers selected two groups: a treatment group and a control group; consisting of 30 respondents, respectively. The number of respondents representing each group is sufficient to carry out this study (Hogg et al., 2018) as referring to (Gay et al., 2012), the minimum requirement to carry out experimental research is 15 respondents per group.

This study employed two types of instruments; RTQ to measure science achievement and CTTQ, on the other hand, measures students' creative thinking. RTQ is composed of six main questions for short answer and essay that covered content standards of sexual and asexual reproduction, human reproductive system, and factors that affect the development of fetus and infant under reproduction topic in SDCA for Science subject. It was developed with an excellent for both a validity index of 0.96 and a reliability index of 0.87 . The CTTQ, a divergent thinking test, consisting of 15 questions, was developed regarding Torrance Test of Creative Thinking (Anwar et al., 2012). The questions involved drawing picture construction activities, picture completion, and repeated figures of lines and circles. Besides, respondents should respond to the stimulus of pictures given in writing. CTTQ had been evaluated based on scoring components of originality, fluency, flexibility, and elaboration indicators. CTTQ had an outstanding validity index of 1.00 and a reliability index of 0.90 . Data normality and homogeneity of variance were tested and reported to meet the assumptions before doing inferential analyses of Pearson correlation and one-way ANOVA tests in verifying the hypotheses.

\section{RESULTS AND DISCUSSION}

Before beginning inferential analysis, the distribution of data is essential to be checked. The Skewness and Kurtosis values of the pretest and posttest of the RTQ and CTTQ for the treatment and control groups are between -2 to +2 . This numerical method showed that the data are normally distributed (Hussin et al., 2014). By using the normality test, researchers chose the Shapiro-Wilk Test as it produces a better power than the Kolmogorov-Smimov Test (Ghasemi \& Zahediasl, 2012). The findings implied that the pretest and posttest data of the RTQ and CTTQ for both groups were normally distributed $(\rho>0.05)$. Therefore, a parametric test was used in this study.

Besides, an equality or homogeneity of variance test should be done through Levene's Test, known as FTest which explains the need to either meet the assumption of that both groups have the same variance in dependent variable (pretest scores). The test was carried out via a procedure of independent sample t-test. Findings showed that there is no significant difference between pretest scores of RTQ for the treatment group $(M=37.13, S D=4.032)$ and control group $(M=35.43, S D=4.066) ;[t(58)=-1.626, \rho=.109]$. In fact, there is no significant difference between pretest scores of CTTQ for the treatment group $(M=41.40, S D=4.523)$ and control group $(\mathrm{M}=42.27, \mathrm{SD}=4.417) ; \mathrm{t}(58)=.751, \rho=.456]$.

Table 1. One-way ANOVA of fluency on science achievement level of the treatment group

\begin{tabular}{|c|c|c|c|c|c|c|}
\hline Indicator & & $\begin{array}{c}\text { Sum of } \\
\text { squares }\end{array}$ & df & Mean square & $F$ & Sig. \\
\hline Fluency & $\begin{array}{c}\text { Between groups } \\
\text { Within groups } \\
\text { Total }\end{array}$ & $\begin{array}{l}21.994 \\
55.872 \\
77.867\end{array}$ & $\begin{array}{c}2 \\
27 \\
29\end{array}$ & $\begin{array}{c}10.997 \\
2.069\end{array}$ & 5.314 & .011 \\
\hline
\end{tabular}


One-way ANOVA in Table 1 shows a statistically significant difference between the creative thinking indicator of fluency based on the science achievement level of the treatment group $[F(2.27)=5.314, \rho=$ 0.011]. It is explained in Table 2 in which students of excellent achievement with Grade $A(M=19.50, S D=$ 1.000) differed from students of good achievement with grade $C(M=16.57, S D=1.512)$ based on the indicator of fluency. Hence, the null hypothesis, $\mathrm{H}_{01}$ is rejected.

Table 2. Tukey HSD test of fluency on science achievement level of the treatment group

\begin{tabular}{cccccc}
\hline Indicator & $\begin{array}{c}\text { Science achievement } \\
\text { level }(\mathbf{I})\end{array}$ & $\begin{array}{c}\text { Science } \\
\text { achievement } \\
\text { level }(\mathrm{J})\end{array}$ & $\begin{array}{c}\text { Mean difference } \\
(\mathrm{I}-\mathrm{J})\end{array}$ & Std. error & Sig. \\
\hline \multirow{5}{*}{ Fluency } & Excellent & Honors & 1.711 & .791 & .096 \\
& Grade A) & Good & $2.929^{*}$ & .902 & .008 \\
\cline { 2 - 6 } & Honors & Excellent & -1.711 & .791 & .096 \\
& (Grade B) & Good & 1.218 & .636 & .154 \\
\cline { 2 - 6 } & Good & Excellent & $-2.929^{*}$ & .902 & .008 \\
& (Grade C) & Honors & -1.218 & .636 & .154 \\
\hline
\end{tabular}

${ }^{\bar{*}}$ The mean difference is significant at the .05 level

Conversely, Table 3 shows a statistically significant difference between the creative thinking indicator of elaboration based on the science achievement level of the control group $[F(2.27)=3.658, \rho=0.039]$. It is explained in Table 4 that students of honors achievement with Grade $B(M=8.22, S D=2.906)$ differed from students of satisfactory achievement with Grade $D(M=4.33, S D=3.445)$ based on the indicator of elaboration. Thus, the null hypothesis, $\mathrm{H}_{02}$ is rejected.

Table 3. One-Way ANOVA of elaboration on science achievement level of the control group

\begin{tabular}{ccccccc}
\hline \multirow{2}{*}{ Indicator } & & Sum of & df & Mean square & F & Sig. \\
& & Squares & & & & \\
& Between Groups & 59.244 & 2 & 29.622 & 3.658 & .039 \\
Elaboration & Within Groups & 218.622 & 27 & 8.097 & & \\
& Total & 277.867 & 29 & & & \\
\hline
\end{tabular}

Table 4. Tukey HSD test of elaboration on science achievement level of the control group

\begin{tabular}{cccccc}
\hline Indicator & $\begin{array}{c}\text { Science achievement } \\
\text { level }(\mathbf{I})\end{array}$ & $\begin{array}{c}\text { Science } \\
\text { achievement } \\
\text { level }(\mathrm{J})\end{array}$ & $\begin{array}{c}\text { Mean difference } \\
(\mathrm{I}-\mathrm{J})\end{array}$ & Std. error & Sig. \\
\hline \multirow{5}{*}{ Elaboration } & Honors & Good & .756 & 1.200 & .805 \\
& (grade B) & Satisfactory & $3.889^{*}$ & 1.500 & .039 \\
\cline { 2 - 7 } & Good & Honors & -.756 & 1.200 & .805 \\
& (grade C) & Satisfactory & 3.133 & 1.375 & .076 \\
\cline { 2 - 7 } & Satisfactory & Honors & $-3.889^{*}$ & 1.500 & .039 \\
(grade D) & Good & -3.133 & 1.375 & .076 \\
\hline
\end{tabular}

* The mean difference is significant at the .05 level

Table 5 reflects the relationship between creative thinking and scientific achievement of the treatment and control groups. The results showed that there was no statistically significant relationship between creative thinking and science learning achievement for the treatment group $(r=.220, \rho=0.243)$ and the control group $(r$ $=.308, \rho=0.098)$. The null hypothesis, $\mathrm{H}_{03}$, and $\mathrm{H}_{04}$ are accepted. It shows that students with high creative thinking skills do not necessarily excel in scientific achievement. There were students in the treatment group with a creative and very creative level who also obtained an honor achievement (grade B) and good (grade C) in addition to an excellent level (grade A). Besides, in the control group, students with the same level of creative thinking as the treatment group obtained satisfactory (grade B), good (grade C), and satisfying (grade D) achievement levels after the implementation of the intervention. It is in line with (Nori et al., 2018), that cognitive ability (measured by academic achievement) does not necessarily become necessary in shaping one's creativity. Also, the overall results of creative thinking that do not correlate with science learning achievement are evidence that between these variables shows consistency in whatever learning strategies are applied. 
Table 5. Correlation between creative thinking and science achievement amongst treatment and control group

\begin{tabular}{lcccc}
\hline & \multicolumn{2}{c}{ Treatment } & \multicolumn{2}{c}{ Control } \\
\cline { 2 - 5 } & Pearson correlation & Sig. (two-tailed) & Pearson correlation & Sig. (two-tailed) \\
\hline Creative thinking & .220 & .243 & .308 & .098 \\
Originality & .050 & .794 & .327 & .078 \\
Fluency & .463 & $.010^{* *}$ & -.012 & .951 \\
Flexibility & .060 & .753 & -.020 & .917 \\
Elaboration & .121 & .524 & .280 & .133 \\
\hline
\end{tabular}

Nevertheless, these findings imply that there is a moderate and statistically significant relationship (Cohen, 1988) and a positive relationship between indicators of creative thinking fluency and scientific achievement $(r=$ $.463, \rho=0.010)$ of the treatment group $\left(\mathrm{H}_{05}\right.$ rejected). These results are following the ANOVA data in Table 1 which proves that learning based on the Celik STEM Module through the engineering design process can improve the fluency of creativity, especially students can develop so many ideas that are relevant and meaningful (indicators of high fluency) to solve problems according to the activities shown in the module. As has been eloquently stated by (Siew \& Ambo, 2018), the engineering design process can foster students' confidence in generating and exchanging ideas and trying to help each other produce excellent and final quality products. It contributes to the development of positive student creativity (Siew et al., 2016).

There was no statistically significant relationship between indicators of creative thinking originality, fluency, flexibility, elaboration, and scientific achievement for the control group. Therefore, the null hypothesis, $\mathrm{H}_{06}$ is accepted. It contrasts with the ANOVA data obtained in Table 3, which shows a significant difference in elaboration indicators based on the level of scientific achievement. Although students who follow traditional teaching can also develop better in elaborate creative thinking, which can explain specific ideas in detail, the weakness can be seen that the details sometimes fail to explain the main idea (Bermejo et al., 2013). Overall, the findings for both groups support the research conducted by (Jauk et al., 2013) that cognitive abilities have different influences on specific creativity domains (originality, fluency, flexibility, and elaboration). It is because creativity is not in the same construct but exists based on certain domains or criteria (Nori et al., 2018).

Strengthening STEM as one of the critical initiatives in Malaysian Education Blueprint 2013-2025 can produce a holistic future generation in all aspects not only excellent in academic, but it can even highlight their talents in certain areas too which the country needs more creative thinkers as the engine for educational development (MoE, 2013; Rauf et al., 2017). While there have been efforts, like introducing $21^{\text {st }}$ Century classrooms, i-Think projects, and STEM programs, more needs to be done to capture and embed creativity into the national curriculum. In this study, the findings suggest that the aspect of creative thinking should be given more attention in STEM teaching and learning because it is one of the higher-order thinking skills components that is important to be highlighted in the curriculum transformation in terms of pedagogy. The six strands of SSSC, i.e., science and technology; communication; spirituality; attitude and values; humanities; personal competence; and physical development and aesthetics that form the fundamentals of curriculum development in Malaysia are evident in the SDCA where the six of them support to each other with creative thinking, critical thinking, and innovativeness (CDD, 2014, 2016).

In addition to pedagogy, the enculturation of creative thinking amongst students starting from school is quite an essential goal (Peterson \& Deal, 2016) because the creative thinking of Malaysian students is still at a low level (Bajuri et al., 2019). The importance of this aspect is acknowledged by Mahmud (2011) that making creativity a priority in the national agenda gives the country a more significant competitive foothold in an increasingly complex global economy. One of the biggest concerns is how one can be more creative or come up with better ideas when it comes to creativity. Thus, creative thinking is seen as one of the components that can contribute to better academic achievement (Bajuri et al., 2019) especially in science teaching and learning.

Specific studies related to the four indicators in creative thinking and their relationships with students' academic achievement are still poorly implemented in Malaysia (Bajuri et al., 2019) especially to view the impact of implementing STEM teaching-learning in Science subject. Nonetheless, this study is slightly similar to those done by Bajuri et al (2019); and that showed a statistically significant and weak and positive relationship between creative thinking and physics achievement. The interpretation of 'weak' according to Cohen (1988) is said to be too little, or there may be a correlation based on interpretation (Idris, 2013). A study by Bahaudin (2011); and Candrasekaran (2013) reported similar findings with the researchers. Unlike the study conducted by Nami et al (2014), it showed that there is a statistically significant and strong and positive relationship between indicators of flexibility and academic achievement. The study by Anwar et al (2012) showed a statistically significant and positive relationship between creative thinking of all indicators and science achievement. The findings in this study, as well as the previous studies, explain that there may be some limitations by several factors as according to (Candrasekaran, 2013), the number of subjects in his study is about 118 , compared to the study conducted by the researchers is only 60 ; and it is quite challenging to explain 
the relationship between creative thinking and academic achievement. This view is supported by Anwar et al (2012), it is crucial to consider the sample size, environmental setup, and some other variables playing some role for such findings. The relationship might be altered when examining a different level of scientific achievement and employing a different creative thinking measurement (Anwar et al., 2012; Candrasekaran, 2013). Besides, the maturity factor (age) is proven to influence in this regard (Nori et al., 2018).

As implication for teachers, creative thinking skills that lead to creativity may be facilitated by using more authentic tasks in school, such as utilizing an integrated STEM approach that connects four disciplines, allowing students to enrich their learning experiences. As a result of this, students apply science and mathematics concepts to think logically, critically, and creatively in solving real-world problems based on steps in the engineering design process. Besides, teachers need to admit that there is a wide range of creative thinking found within their students as well as realize that creative thinking as necessary and finds ways to enhance and promote the development of their students.

\section{CONCLUSION}

This study provides empirical support for the relationship between creative thinking, creative thinking indicators, and science achievement. Based on the results and data gathered from the 60 students who participated in this study, it is clearly shown that the use of an integrated STEM-based module (Celik STEM Module) has significant results towards students' creative thinking of fluency indicator and science achievement compared to the traditional teaching. The findings support the significance of teaching in a creative environment through integrated STEM that encourages creative thinking skills in solving real-world problems to improve the chance of academic success for all students.

\section{ACKNOWLEDGEMENT}

The highest appreciation goes to all the experts involved in the validation of the Celik STEM Module, SMKA Baling, Kedah, Malaysia, and all students involved in this research.

\section{REFERENCES}

Anwar, M. N., Aness, M., Khizar, A., Naseer, M., \& Muhammad, G. (2012). Relationship of creative thinking with the academic achievements of secondary school students. International Interdisciplinary Journal of Education, 1(3), 1-4. Retrieved from https://www.researchgate.net/publication/338549060_Relationship _of_Creative_Thinking_with_the_Academic_Achievements_of_Secondary_School_Students

Asghar, A., Ellington, R., Rice, E., Johnson, F., \& Prime, G. M. (2012). Supporting STEM education in secondary science contexts. Interdisciplinary Journal of Problem-Based Learning Volume, 6(2), 85-125. doi: https://doi.org/10.7771/1541-5015.1349

Asrizal, F., Amran, A., \& Ananda, A. (2017). Need analysis to develop adaptive contextual learning model. Proceeding of the 2nd International Conference on Teacher Education, 1, 78-83. Retrieved from https://osf.io/gxqev/download/?format=pdf

Bahaudin, M. Z. Bin. (2011). Hubungan kreativiti dengan pencapaian fizik pelajar tingkatan empat di Daerah Hulu Selangor [Universiti Pendidikan Sultan Idris]. In Universiti Pendidikan Sultan Idris. Retrieved from http://malrep.uum.edu.my/rep/Record/my.upsi.ir.359

Bahrum, S., Wahid, N., \& Ibrahim, N. (2017). Integration of STEM education in Malaysia and why to STEAM. International Journal of Academic Research in Business and Social Sciences, 7(6), 645-654. doi: https://doi.org/10.6007/ijarbss/v7-i6/3027

Bajuri, M. R., Maat, S. M., \& Halim, L. (2019). Relationship between creative thinking skills with learning achievement on physics concept application. February, 193-198. Retrieved from https://www.research gate.net/publication/331272211_relationship_between_creative_thinking_skills_with_learning_achievem ent_on_physics_concept_application/related

Bermejo, R., Prieto, M. D., Fernández, M. C., Soto, G., \& Sainz, M. (2013). A cognitive-creative profile of emotional talent. Journal of New Approaches in Educational Research, 2(1), 12-16. doi: https://doi.org/ 10.7821/naer.2.1.12-16

Binkley, M., Erstad, O., Herman, J., Raizen, S., Ripley, M., Miller-Ricci, M., \& Rumble, M. (2012). Defining twenty-first century skills. In P. Griffin, B. McGaw, \& E. Care (Eds.), Assessment and teaching of 21st 
century skills (pp. 17-66). Springer. doi: https://doi.org/10.1007/978-94-007-2324-5

Bunyamin, M. A. H. (2015). Pendidikan STEM Bersepadu: Perspektif global, perkembangan semasa di Malaysia, dan langkah kehadapan. The Bulletin of the Johor Association of Science and Mathematics Education, 25(1), 1-6. Retrieved from https://www.researchgate.net/publication/301567750

Bunyamin, M. A. H., \& Finley, F. (2016). STEM Education in Malaysia: Reviewing the current physics curriculum STEM education from international perspectives. International Conference of Association for Science Teacher Education. Retrieved from https://www. researchgate.net/publication/294722510

Candrasekaran, S. (2013). Creativity and academic achievement of higher secondary school students in Tamilnadu. International Journal of Humanities and Social Science Invention, 3(8), 32-36. Retrieved from http://www.ijhssi.org/papers/v3(8)/Version-1/F0381032036.pdf

CDD, (Curriculum Development Division). (2014). Elemen KBAT dalam sumber. Kuala Lumpur: Kementerian Pendidikan Malaysia. Retrieved from https://www.moe.gov.my/menumedia/media-cetak/penerbitan /kbat/1334-elemen-kbat-dalam-sumber/file

CDD, (Curriculum Development Division). (2016). Panduan pelaksanaan sains, teknologi, kejuruteraan, dan matematik (STEM) dalam pengajaran dan pembelajaran. Kuala Lumpur: Kementerian Pendidikan Malaysia. Retrieved from https://www.slideshare.net/mohdgazali1/2016-1226-panduan-pelaksanaanstem-dalam-pembelajaran-dan-pengajaran-150779012?from_action=save

Cohen, J. (1988). Statistical power analysis for the behavioral sciences. In Statistical Power Analysis for the Behavioral Sciences. Lawrence Erlbaum Associate. doi: https://doi.org/10.4324/9780203771587

English, L. D. (2016). STEM education K-12: Perspectives on integration. International Journal of STEM Education, 3(1), 1-8. doi: https://doi.org/10.1186/s40594-016-0036-1

Fidan, N. K., \& Ay, T. S. (2016). Acquisition of operational environmental literacy in social studies course. International Journal of Environmental and Science Education, 11(13), 5951-5968. doi: https://doi.org/ 10.12973/ijese.2014.22a

Gay, L. R., Mills, G. L., \& Airasian, P. (2012). Educational research: Competencies for analysis and application. Pearson. Retrieved from http://englishlangkan.com/produk/E Book Educational Research L R Gay Pearson 2012.pdf

Ghasemi, A., \& Zahediasl, S. (2012). Normality tests for statistical analysis: A guide for non-statisticians. International Journal of Endocrinology and Metabolism, 10(2), 486-489. doi: https://doi.org/10.5812/ ijem.3505

Hock, L. C. (2016). STEM roadmap to meet growing demand for engineers in the future. Jurutera. Retrieved from http://www.myiem.org.my/content/press_\%0Arelease-305.aspx

Hogg, R. V., Tanis, E. A., \& Zimmerman, D. L. (2018). Probability and statistical inference. Pearson. Retrieved from https://www.pearsonhighered.com/assets/preface/0/1/3/5/013518939X.pdf.

Hussin, F. Bin, Ali, J., \& Noor, M. S. Z. (2014). Kaedah penyelidikan \& analisis data SPSS. UUM Press. Retrieved from http://lintas.uum.edu.my:8080/elmu/index.jsp?module=webopac-I\&action=fullDisplayRe tri ever.jsp\&szMa terialNo $=0000805115$

Idris, N. (2013). Penyelidikan dalam pendidikan (p. 570). McGraw-Hill.

Jauk, E., Benedek, M., Dunst, B., \& Neubauer, A. C. (2013). The relationship between intelligence and creativity: New support for the threshold hypothesis by means of empirical breakpoint detection. Intelligence, 41(4), 212-221. doi: https://doi.org/10.1016/j.intell.2013.03.003

Jayarajah, K., Saat, R. M., \& Rauf, R. A. A. (2014). A review of science, technology, engineering \& mathematics (STEM) education research from 1999-2013: A Malaysian perspective. Eurasia Journal of Mathematics, Science and Technology Education, 10(3), 155-163. doi: https://doi.org/10.12973/eura sia.2014.1072a

Kadir, K. H. B. A., Nordin, N. M., \& Iksan, Z. (2017). Kesepaduan elemen analogi dan teknologi maklumat dalam modul sains (e-smart) bagi menerapkan kemahiran berfikir kreatif murid di Abad 21. Simposium Pendidikan Di Peribadikan: Perspektif Risalah An-Nur (SPRiN2017), 162-170. Retrieved from http://conference.ukm. my/sprin/index.php/sprin/sprin/paper/view/60/23

Mahmud, D. A. G. (2011). Haluan kerja pendidikan: Merealisasikan agenda transformasi negara. Retrieved from http://appsjohor.moe.gov.my/jpnjohor/v6/pdf/haluan_kerja_pendidikan.pdf

McFarlane, D. A. (2013). Understanding the challenges of science education in the 21st century: New opportunities for scientific literacy. International Letters of Social and Humanistic Sciences, 4, 35-44. doi: https://doi.org/10.18052/www.scipress.com//LSHS.4.35

McKechan, S., \& Ellis, J. (2014). Collaborative learning in the Scottish curriculum for excellence: The 
challenges of assessment and potential of multi-touch technology. Education 3-13, 42(5), 475-487. doi: https://doi.org/10.1080/03004279.2012.717959

MoE, M. of E. (2013). Malaysia education blueprint 2013 - 2025 (Preschool to post-secondary education). Ministry of Education Malaysia. Retrieved from https://www.moe.gov.my/menumedia/mediacetak/penerbitan/dasar/1207-malaysia-education-blueprint-2013-2025/file

Mustafa, N., Ismail, Z., Tasir, Z., \& Mohamad Said, M. N. H. (2016). A meta-analysis on effective strategies for integrated STEM education. Advanced Science Letters, 22(12), 4225-4288. doi: https://doi.org/10.1166/ asl.2016.8111

Mustaffa, N., \& Ismail, Z. (2015). Problem-Based Learning (PBL) in schools: A meta-analysis. 12th International Conference of The Mathematics Education into the 21st Century Project The Future of Mathematics Education in a Connected World, September 2014. Retrieved from https://madipedia.de/ wiki/MEC_21_-_12th_International_Conference_of_The_Mathematics_Education_into_the_21st_Centu ry_Project

Nami, Y., Marsooli, H., \& Ashouri, M. (2014). The relationship between creativity and academic achievement. Procedia - Social and Behavioral Sciences, 114(1962), 36-39. doi: https://doi.org/10.1016/j.sbspro. 2013.12.652

Nori, R., Signore, S., \& Bonifacci, P. (2018). Creativity style and achievements: An investigation on the role of emotional competence, individual differences, and psychometric intelligence. Frontiers in Psychology, 9(OCT), 1-11. doi: https://doi.org/10.3389/fpsyg.2018.01826

Osman, K., \& Saat, R. M. (2014). Editorial: Science, Technology, Engineering and Mathematics (STEM) education in Malaysia. Eurasia Journal of Mathematics, Science and Technology Education, 10(3), 153-154. doi: https://doi.org/10.12973/eurasia.2014.1077a

Peterson, K. D., \& Deal, T. E. (2016). The shaping school culture fieldbook. In Shaping School Culture. Jossey-Bass A Wiley Imprint. doi: https://doi.org/10.1002/9781119210214

Piergiovanni, P. R. (2014). Creating a critical thinker. College Teaching, 62(3), 86-93. doi: https://doi.org/ 10.1080/87567555.2014.896775

Prayogi, S., \& Yuanita, L. (2018). Critical-inquiry-based-learning: model of learning to promote critical thinking ability of pre-service teachers. IOP Conf. Series: Journal of Physics: Conf. Series, 947, 12013. doi: https://doi.org/10.1088/1742-6596/947/1/012013

Rauf, R. A. A., Rasul, M. S., Sathasivam, R., \& Rahim, S. S. A. (2017). Training of trainers STEM build program for primary science teachers: An initiative towards STEM education in school. International Conference New Perspectives in Science Education. Retrieved from http://eprints.um.edu.my/ id/eprint/17410

Scott, C. L. (2015). The futures of learning 2: What kind of learning for the 21st Century? https://unesco.org/ ark:/48223/pf0000242996

Serrat, M. A., Dom, A. M., Buchanan, J. T., Williams, A. R., Efaw, M. L., \& Richardson, L. L. (2014). Independent learning modules enhance student performance and understanding of anatomy. Anatomical Sciences Education, 7(5), 406-416. doi: https://doi.org/10.1002/ase.1438

Siew, N. M., \& Ambo, N. (2018). Development and evaluation of an integrated project-based and STEM teaching and learning module on enhancing scientific creativity among fifth graders. Journal of Baltic Science Education, 17(6), 1017-1033. doi: https://doi.org/10.33225/jbse/18.17.1017

Siew, N. M., Goh, H., \& Sulaiman, F. (2016). Integrating STEM in an engineering design process: The learning experience of rural secondary school students in an outreach challenge program. Journal of Baltic Science Education, 15(4), 477-493. Retrieved from http://journals.indexcopernicus.com/abs tract.php?icid $=1217790$

Sturyf, A., Loof, H. de, Pauw, J. B., \& Petegem, P. van. (2019). Students' engagement in different STEM learning environments: Integrated STEM education as promising practice? International Journal of Science Education, 41(10). doi: https://doi.org/10.1080/09500693.2019.1607983

Sulaiman, T., Ayub, A. F. M., \& Sulaiman, S. (2015). Curriculum change in English language curriculum advocates higher order thinking skills and standards-based assessments in Malaysian primary schools. Mediterranean Journal of Social Sciences, 6(2), 494-500. doi: https://doi.org/10.5901/mjss.2015.v6n2p 494

Thomas, B., \& Watters, J. J. (2015). Perspectives on Australian, Indian and Malaysian approaches to STEM education. International Journal of Educational Development, 45, 42-53. doi: https://doi.org/10.1016/j.ije dudev.2015.08.002 